\title{
Lipemic Specimen
}

National Cancer Institute

\section{Source}

National Cancer Institute. Lipemic Specimen. NCI Thesaurus. Code C70715.

A specimen that consists of or contains excessive amounts of fat and fatty substances. 